\title{
Drug Reaction with Eosinophilia and Systemic Symptoms (DRESS) syndrome with ciprofloxacin
}

\section{Sameh Sayhi, Tayssir Ben Achour}

\author{
Internal Medicine Department, Military Hospital of Tunis, Tunis, Tunisia
}

Corresponding author: Dr. Sameh Sayhi, E-mail: sameh_sayhi@yahoo.fr

Drug Reaction with Eosinophilia and Systemic Symptoms (DRESS) syndrome is a severe adverse drug-induced reaction, characterized by generalized skin rash associated with hypereosinophilia and organ involvement [1]. The syndrome is most frequently caused by allopurinol, antiepileptics [2], and antibiotics (sulfamethoxazole, dapsone, minocycline, and vancomycin). Dress syndrome associated with ciprofloxacin is rare.

We report the observation of 88-year-old women hospitalized for urinary tract infection treated by ciprofloxacin $1.5 \mathrm{~g} / \mathrm{d}$. seven days later, the patient presented generalized erythematous lesions associated with pruritus, edema of the hands and cheilitis (Figs. la and lb). Biological tests objectified renal and hepatic impairment. An elevated eosinophil count was objectified: 51380 cells $/ \mathrm{mm}^{3}$. Pharmacovigilance survey was carried out confirming the drug origin. Ciprofloxacin was stopped and the patient was treated by corticosteroids with favorable outcome.

DRESS syndrome is a serious and potentially lifethreatening toxic epidermis due to multi-visceral involvement. In most of the above described cases, systemic corticosteroids were used with success.

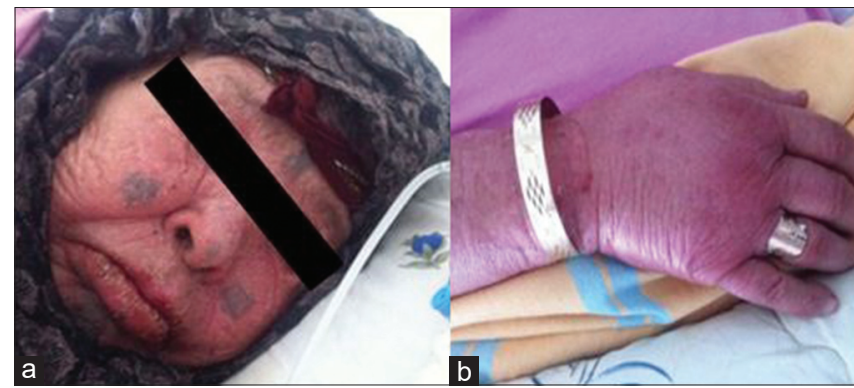

Figure 1: $a$ and $b$ Cheleitis and hand edema in women with DRESS syndrome (ciprofloxacin).

\section{REFERENCES}

1. Kaabi W, Zaiem A, Aouinti I, Charfi O, Kastalli S, El Aidli S, et al. Drug reaction with eosinophilia and systemic symptoms in pediatric patients: A clinicopathological study of 16 cases in the National Center of Pharmacovigilance of Tunisia. Therapie. 2019;(19):595730063-0.

2. Shear NH, Spielberg SP. Anticonvulsant hypersensitivity syndrome. In vitro assessment of risk. J Clin Invest. 1988;82:1826-2.

Copyright by Sameh Sayhi, et al. This is an open-access article distributed under the terms of the Creative Commons Attribution License, which permits unrestricted use, distribution, and reproduction in any medium, provided the original author and source are credited.

Source of Support: Nil, Conflict of Interest: None declared.

\footnotetext{
How to cite this article: Sayhi S, Achour TB. Drug Reaction with Eosinophilia and Systemic Symptoms (DRESS) syndrome with ciprofloxacin. Our Dermatol Online. 2020;11(2): 189.

Submission: 22.05.2019; Acceptance: 23.07.2019

DOI: 10.7241 /ourd.20202.21
} 